\title{
Characteristics of Critically Ill Patients with Covid-19: A Cohort Study in Medical Intensive Care Unit (Mulhouse, France)
}

\author{
POINTURIER Valentin, MD ${ }^{1}$, VIROT Edouard, $M D^{1}$, DEGOUL Samuel, MD2, MATHIEN Cyrille, MD', \\ POIDEVIN Antoine, MD' , PINTO Luis, MD ${ }^{1}$, LABRO Guylaine, $M D^{1}$, RABOUEL Yannick, MD ${ }^{1}$, BODUR \\ Gokhan, MD ${ }^{1}$, JANDEAUX Louise Marie, MD ${ }^{1}$, LESTHIEVENT Thomas ${ }^{1}$, MOOTIEN Joy, MD ${ }^{1}$ and KUTEIFAN \\ Khaldoun, $M D^{1 *}$
}

${ }^{1}$ Service de Réanimation Médicale, GHR Mulhouse Sud-Alsace, Mulhouse, France

${ }^{2}$ Direction de la Recherche Clinique, GHR Mulhouse Sud-Alsace, Mulhouse, France

\begin{abstract}
Background: The outbreak of the novel coronavirus SARS-CoV-2 began in the east of France during the first days of March after a religious meeting gathering about 2000 people, which took place in Mulhouse from February $17^{\text {th }}$ to $24^{\text {th }} 2020$. We describe the characteristics of patients admitted to our intensive care unit (ICU)

Method: We carried out a retrospective analysis of demographic and clinical characteristics of patients admitted to our 20 beds medical ICU from March $2^{\text {nd }}$ to April $2^{\text {nd }} 2020$, with diagnosis of Covid-19. Data were collected during the first 3 days of hospitalization in ICU.

Results: Ninety-seven patients were admitted to our ICU during 1 month. The mean ( \pm SD) age of the patients was 60 \pm 11 years; $74 \%$ were men. The mean duration of symptoms before ICU admission was $10 \pm 5$ days. Lymphopenia was common with a median lymphocyte count of 670 per cubic millimeter. C - reactive protein was $155.5 \mathrm{mg} / \mathrm{L}$. Fibrinogen was $7 \mathrm{~g} / \mathrm{L}$ and D-Dimers were $1164 \mathrm{ng} / \mathrm{mL}$. Chest radiography obtained in all the patients on ICU admission showed bilateral pulmonary opacities. Ninety-three patients $(95.8 \%)$ required intubation and mechanical ventilation. $\mathrm{PaO}_{2}: \mathrm{FiO}_{2}$ ratios were consistent with moderate-to-severe ARDS (median $143 \mathrm{mmHg}$ ). Twenty-nine patients (29.9\%) were placed in a prone position. As of April $2^{\text {nd }}, 60$ (61.8\%) medically stabilized patients had to be transferred to other ICU, 18 (18.5\%) died, $8(8.2 \%)$ had been discharged but remained in the hospital and $15(15.5 \%)$ were still ventilated in our unit.

Conclusion: Severe form of Covid-19 is marked by systemic hyper-inflammation and coagulation disturbances associated with a new pattern of Acute Respiratory Distress Syndrome (ARDS). Almost all the patients required intubation and mechanical ventilation with high $\mathrm{FiO}_{2}$ and high $\mathrm{PEEP}$ to ensure proper oxygenation. In patients with a $\mathrm{PaO}_{2}: \mathrm{FiO}_{2}$ ratio less than $150 \mathrm{mmHg}$ during the first three days ( $30 \%$ of total), prone positioning was performed with a sustainable benefit.

Keywords

COVID-19, ARDS, SARS-COV-2, Prone position

Abbreviations

SARS-CoV-2: Severe Acute Respiratory Syndrome coronavirus-2; COVID-19: Coronavirus Disease 2019; ICU: Intensive Care Unit; GHRMSA: Groupe Hospitalier de la Region de Mulhouse et Sud Alsace; RT-PCR: Reverse transcriptase-polymerasechain-reaction; CT: Computed-Tomography; RSV: Respiratory Syncytial Virus; BIS: Bispectral Index Score; TOF: Train-ofFour; $\mathrm{PaO}_{2}$ : Partial Arterial Oxygen Pressure; $\mathrm{FiO}_{2}$ : Inspired Fraction of Oxygen; PEEP: Positive End Expiratory Pressure; BMI: Body Mass Index; ARDS: Acute Respiratory Distress Syndrome
\end{abstract}

\section{Background}

The outbreak of a novel coronavirus in Wuhan, the capital city of Hubei, China in December 2019 raised a worldwide concern. Cases of pneumonia of unknown origin were first described and the pathogen responsible was later identified as being a novel beta coronavirus [1-3]. Named as the Severe Acute Respiratory Syndrome coronavirus-2 (SARS-CoV-2) this virus is responsible of the coronavirus disease 2019 (Covid-19)
[4]. The outbreak began in the east of France during the first days of March after a religious meeting gathering about 2000 people, which took place in Mulhouse from $17^{\text {th }}$ to $24^{\text {th }} \mathrm{Feb}$ ruary 2020 [5].

Our hospital organizational structure has been drastically adapted so as to deal with the massive flood of patients presenting Covid-19 infection. Emergency Department had to be reorganized, COVID units were created for patients with mild 
Citation: Lakhanpaul M, Rosenthal DM, Lakhanpua M, et al. (2020) Reverse Innovation: Could Learning From LMIC Child Health Programmes Support HIC to Equitably and Efficiently Address Child Health Needs Post COVID-19?. Ann Public Health Reports 4(1):53-61

Table 1: Demographic characteristics of the patients at baseline.

\begin{tabular}{|c|c|}
\hline Characteristic & Patients $($ No $=97)$ \\
\hline Mean Age (range), y & $60(31-85)$ \\
\hline \multicolumn{2}{|l|}{ Sexe No (\%) } \\
\hline Male & $72(74.2)$ \\
\hline Female & $25(25.8)$ \\
\hline $\mathrm{BMI} \mathrm{Kg} / \mathrm{m}^{2}($ Mean $\pm \mathrm{sd})$ & $31.4 \pm 6.2$ \\
\hline SAPS II (mean \pm sd) & $41.5 \pm 13$ \\
\hline SOFA (median) & 6 \\
\hline \multicolumn{2}{|l|}{ Coexisting disorders No (\%) } \\
\hline Arterial hypertension & $45(46.4)$ \\
\hline Diabetes mellitus & $28(28.9)$ \\
\hline Dyslipidemia & $22(22.7)$ \\
\hline Coronary artery disease & $16(16.5)$ \\
\hline Ischemic stroke & $5(5.2)$ \\
\hline Chronic kidney disease & $8(8.2)$ \\
\hline Chronic liver disease & 0 \\
\hline HIV & $3(3.1)$ \\
\hline Cancer & $5(5.2)$ \\
\hline COPD & $7(7.2)$ \\
\hline Asthma & $8(8.2)$ \\
\hline Obstructive sleep apnea & $18(18.6)$ \\
\hline Smoking & $3(3.1)$ \\
\hline Others & $10(10.4)$ \\
\hline \multicolumn{2}{|l|}{ Medications No (\%) } \\
\hline ARB & $21(21.6)$ \\
\hline CEI & $14(14.4)$ \\
\hline$\beta$ blockers & $23(23.7)$ \\
\hline Calcic inhibitors & $18(18.6)$ \\
\hline Thiazides & $16(16.5)$ \\
\hline Statins & $21(21.6)$ \\
\hline Antidiabetics & $20(20.6)$ \\
\hline Glucocorticoids & $5(5.2)$ \\
\hline Inhaled steroids & $5(5.2)$ \\
\hline Immune suppressors & $5(5.2)$ \\
\hline NSAI drugs & $2(2.1)$ \\
\hline $\begin{array}{l}\text { Mean duration of symptoms before } \\
\text { admission (days } \pm s d \text { ) }\end{array}$ & $10 \pm 5$ \\
\hline \multicolumn{2}{|l|}{ Admission location No (\%) } \\
\hline Home & $49(50.5)$ \\
\hline Hospital transfers & $48(49.5)$ \\
\hline Extubated No. (\%) & $4(4.1)$ \\
\hline Transferred to other ICU unit No. (\%) & 60 (61.9) \\
\hline Died in our unit No./ total No. (\%) & $18(18.6)$ \\
\hline
\end{tabular}

y: Years; BMI: Body Mass Index; SAPS: Simplified Acute Physiology Score; SOFA: Sepsis-related Organ Failure Assessment; HIV: Human immunodeficiency virus; COPD: Chronic Obstruciv Pulmonary Disease; ARB: Angiotensin II Receptor Blocker; CEI: Conversion Enzyme Inhibitor; NSAI: Non-Steroidien Anti-Inflammatory; ICU: Intensive Care Unit. presentation, and the number of intensive care beds was increased to manage patients presenting with severe disease. About 20 patients requiring invasive ventilation were intubated daily during 3 consecutive weeks.

In this cohort study, we describe demographic and clinical characteristics of 97 patients admitted to our 20 beds intensive care unit (ICU) from March $2^{\text {nd }}$ to April $2^{\text {nd }} 2020$.

\section{Method}

The Groupe Hospitalier de la Region de Mulhouse Sud-Alsace (GHRMSA) is a hospital complex including 10 sites with a total capacity of 2612 beds and covering the needs of 480,000 people. Intensive care facilities are located on the main site, Emile Muller Hospital, with a capacity of 824 general beds and 40 intensive care beds. At the beginning of the crisis all the ICU beds were converted into "COVID beds". Within a week, 16 additional beds were added in five operative and post-operative rooms. Scheduled surgical and medical activity was temporarily held. A "no COVID" intensive care unit with 8 beds was created in another post-operative room. On week 3 of the outbreak, a 30 beds mobile ICU was deployed at the hospital parking area by the French army health service.

So as to cope with this massive flood, a national as well as an international cooperation was setup and many patients were transferred by helicopter, trains and military planes to other ICU in France, Germany, Luxembourg and Switzerland. Thereby we retrospectively analyzed demographic and clinical characteristics during the first three days after admission of the patients to our ICU.

\section{Statistical analysis}

Descriptive statistics were used to summarize the data; results are reported as medians and interquartile ranges or means and standard deviations, as appropriate. Categorical variables are summarized as counts and percentages. Analysis was performed with $\mathrm{R}$ software version 4.5.2.

\section{Results}

From March $2^{\text {nd }}$ to April $2^{\text {nd }}, 97$ patients were admitted to our 20 beds ICU with laboratory-confirmed Covid-19, defined by a positive result on a reverse-transcriptase-polymerase-chain-reaction (RT-PCR) assay of a specimen collected on a nasopharyngeal swab.

The demographic and clinical characteristics of the patients are shown in Table 1 . The mean $( \pm S D$ ) age of the pa-

*Corresponding author: Dr. KUTEIFAN Khaldoun, Service de Réanimation Médicale, GHRMSA, Hôpital Emile Muller, 68100 Mulhouse, France

Received: May 28, 2020

Accepted: July 08, 2020

Published online: July 10, 2020

Citation: Valentin P, Edouard V, Samuel D, Cyrille M, Antoine P, et al. (2020) Characteristics of Critically III Patients with Covid-19: A Cohort Study in Medical Intensive Care Unit (Mulhouse, France). Ann Public Health Reports 4(1):55-54 
Citation: Lakhanpaul M, Rosenthal DM, Lakhanpua M, et al. (2020) Reverse Innovation: Could Learning From LMIC Child Health Programmes Support HIC to Equitably and Efficiently Address Child Health Needs Post COVID-19?. Ann Public Health Reports 4(1):53-61

Table 2: Laboratory data at ICU admission and during the first three days.

\begin{tabular}{|c|c|c|c|c|}
\hline \multirow[t]{2}{*}{ Laboratory Data } & \multicolumn{4}{|l|}{$\begin{array}{l}\text { Median } \\
\text { (IQR) }\end{array}$} \\
\hline & Admission & Day 1 & Day 2 & Day 3 \\
\hline White cell count (G/L) & $\begin{array}{l}8.43 \\
(5.29-10.27)\end{array}$ & $\begin{array}{l}8.89 \\
(6.3-10.71)\end{array}$ & $\begin{array}{l}8.46 \\
(6.86-11.12)\end{array}$ & $\begin{array}{l}8.92 \\
(6.47-12.67)\end{array}$ \\
\hline Lymphocyte count (G/L) & $\begin{array}{l}0.67 \\
(0.5-0.93)\end{array}$ & $\begin{array}{l}0.83 \\
(0.59-1.18)\end{array}$ & $\begin{array}{l}0.69 \\
(0.56-0.92)\end{array}$ & $\begin{array}{l}0.7 \\
(0.48-0.87)\end{array}$ \\
\hline Neutrophil count (G/L) & $\begin{array}{l}7.38 \\
(4.37-8.96)\end{array}$ & $\begin{array}{l}7.32 \\
(5-8.84)\end{array}$ & $\begin{array}{l}7.04 \\
(5.53-9.65)\end{array}$ & $\begin{array}{l}7.7 \\
(5.22-10.51)\end{array}$ \\
\hline Hemoglobin (g/dL) & $\begin{array}{l}13 \\
(11.8-14.2)\end{array}$ & $\begin{array}{l}12.4 \\
(11.4-13.4)\end{array}$ & $\begin{array}{l}12.2 \\
(10.9-13.1)\end{array}$ & $\begin{array}{l}11.4 \\
(10.47-12.9)\end{array}$ \\
\hline Platelets (G/L) & $\begin{array}{l}249 \\
(182-293)\end{array}$ & $\begin{array}{l}238 \\
(189-302)\end{array}$ & $\begin{array}{l}237 \\
(203-314)\end{array}$ & $\begin{array}{l}261 \\
(193-309)\end{array}$ \\
\hline $\mathrm{pH}$ & $\begin{array}{l}7.43 \\
(7.34-7.47)\end{array}$ & $\begin{array}{l}7.38 \\
(7.34-7.44)\end{array}$ & $\begin{array}{l}7.39 \\
(7.34-7.43)\end{array}$ & $\begin{array}{l}7.38 \\
(7.34-7.43)\end{array}$ \\
\hline $\mathrm{PaCO}_{2}(\mathrm{mmHg})$ & $\begin{array}{l}36.6 \\
(32.2-46.8)\end{array}$ & $\begin{array}{l}39.4 \\
(36.6-44.8)\end{array}$ & $\begin{array}{l}41.5 \\
(37.3-45)\end{array}$ & $\begin{array}{l}43.6 \\
(39.4-46.4)\end{array}$ \\
\hline $\mathrm{PaO}_{2}(\mathrm{mmHg})$ & $\begin{array}{l}81.6 \\
(67-109.9)\end{array}$ & $\begin{array}{l}88 \\
(79.9-114)\end{array}$ & $\begin{array}{l}87.4 \\
(74.7-102.4)\end{array}$ & $\begin{array}{l}82.6 \\
(72.7-90.3)\end{array}$ \\
\hline Serum bicarbonate (mmol/L) & $\begin{array}{l}23.6 \\
(21.3-25.4)\end{array}$ & $\begin{array}{l}23.7 \\
(21.2-25.2)\end{array}$ & $\begin{array}{l}23.7 \\
(21.8-25.9)\end{array}$ & $\begin{array}{l}24.5 \\
(22.5-26.7)\end{array}$ \\
\hline Lactate (mmol/L) & $\begin{array}{l}1.32 \\
(1.09-1.77)\end{array}$ & $\begin{array}{l}1.43 \\
(1.16-1.75)\end{array}$ & $\begin{array}{l}1.53 \\
(1.22-1.9)\end{array}$ & $\begin{array}{l}1.62 \\
(1.28-1.91)\end{array}$ \\
\hline Urea (mmol/L) & $\begin{array}{l}7.7 \\
(5-10.6)\end{array}$ & $\begin{array}{l}6.35 \\
(4.28-10.15)\end{array}$ & $\begin{array}{l}5.7 \\
(3.8-10.5)\end{array}$ & $\begin{array}{l}7.4 \\
(4.4-12.9)\end{array}$ \\
\hline Creatinine $(\mu \mathrm{mol} / \mathrm{L})$ & $\begin{array}{l}78.5 \\
(61.8-111.5)\end{array}$ & $\begin{array}{l}82 \\
(63.8-119.5)\end{array}$ & $\begin{array}{l}85 \\
(62-120)\end{array}$ & $\begin{array}{l}88 \\
(56.5-160.5)\end{array}$ \\
\hline C-Reactive Protein (mg/L) & $\begin{array}{l}155.5 \\
(103.5-210)\end{array}$ & & & $\begin{array}{l}259.5 \\
(183.2-326.2)\end{array}$ \\
\hline Lipase (N = 73-393 UI/L) & $\begin{array}{l}150 \\
(85-259)\end{array}$ & & & $\begin{array}{l}183 \\
(109-262)\end{array}$ \\
\hline $\begin{array}{l}\text { Creatin Phosphokinase } \\
(\mathrm{N}=26-192 \mathrm{UI} / \mathrm{L})\end{array}$ & $\begin{array}{l}225 \\
(112-649)\end{array}$ & & & $\begin{array}{l}383 \\
(197-947)\end{array}$ \\
\hline $\begin{array}{l}\text { Troponine Ic } \\
(\mathrm{N}<0.045 \mathrm{ng} / \mathrm{mL})\end{array}$ & $\begin{array}{l}0.019 \\
(0.015-0.103)\end{array}$ & & & $\begin{array}{l}0.015 \\
(0.0015-0.028\end{array}$ \\
\hline Albumin (g/L) & $\begin{array}{l}25 \\
(23.8-29)\end{array}$ & & & $\begin{array}{l}19 \\
(17-21)\end{array}$ \\
\hline Prothrombin (\%) & $\begin{array}{l}70 \\
(61.8-78-25)\end{array}$ & & & $\begin{array}{l}63 \\
(75-73)\end{array}$ \\
\hline Factor V (61-142 \%) & $\begin{array}{l}164 \\
(123.2-197.5)\end{array}$ & & & $\begin{array}{l}201 \\
(131.5-212)\end{array}$ \\
\hline $\begin{array}{l}\text { Activated Partial Thromboplastin time } \\
(28.5-30.5 \mathrm{sec} .)\end{array}$ & $\begin{array}{l}30.2 \\
(28.9-33.2)\end{array}$ & & & $\begin{array}{l}30.5 \\
(29.9-39.9)\end{array}$ \\
\hline $\begin{array}{l}\text { Fibrinogen }(\mathrm{g} / \mathrm{L}) \\
(2.13-4.22 \mathrm{~g} / \mathrm{L})\end{array}$ & $\begin{array}{l}7 \\
(5.9-8.6)\end{array}$ & & & $\begin{array}{l}8.3 \\
(6.75-9.7)\end{array}$ \\
\hline $\begin{array}{l}\text { D-dimers } \\
(\mathrm{N}<500 \mathrm{ng} / \mathrm{mL})\end{array}$ & $\begin{array}{l}1164 \\
(717-2663)\end{array}$ & & & $\begin{array}{l}1734 \\
(985-4331)\end{array}$ \\
\hline
\end{tabular}


Citation: Lakhanpaul M, Rosenthal DM, Lakhanpua M, et al. (2020) Reverse Innovation: Could Learning From LMIC Child Health Programmes Support HIC to Equitably and Efficiently Address Child Health Needs Post COVID-19?. Ann Public Health Reports 4(1):53-61

\begin{tabular}{|l|l|l|l|}
\hline $\begin{array}{l}\text { Procalcitonin } \\
(\mathrm{N}<0.5 \mathrm{ng} / \mathrm{mL})\end{array}$ & $\begin{array}{l}0.7 \\
(0.3-2.2)\end{array}$ & \\
\hline Urinary protein (g/L) & $\begin{array}{l}\text { (1.91 } \\
(1.23-2.5)\end{array}$ & \\
\hline $\begin{array}{l}\text { Factor VIII } \\
\text { (N }=56-146 \%)\end{array}$ & & 242 \\
\hline $\begin{array}{l}\text { Antithrombin } \\
(\mathrm{N}=83-126 \%)\end{array}$ & & $(230-291)$ \\
\hline
\end{tabular}

IQR: Inter-Quartile Range; G/L: Giga per liter; g/dL: Gram per deciliter; $\mathrm{PaO}_{2}$ : Partial arterial oxygen pressure; $\mathrm{PaCO}_{2}$ : Partial arterial carbon dioxide pressure.

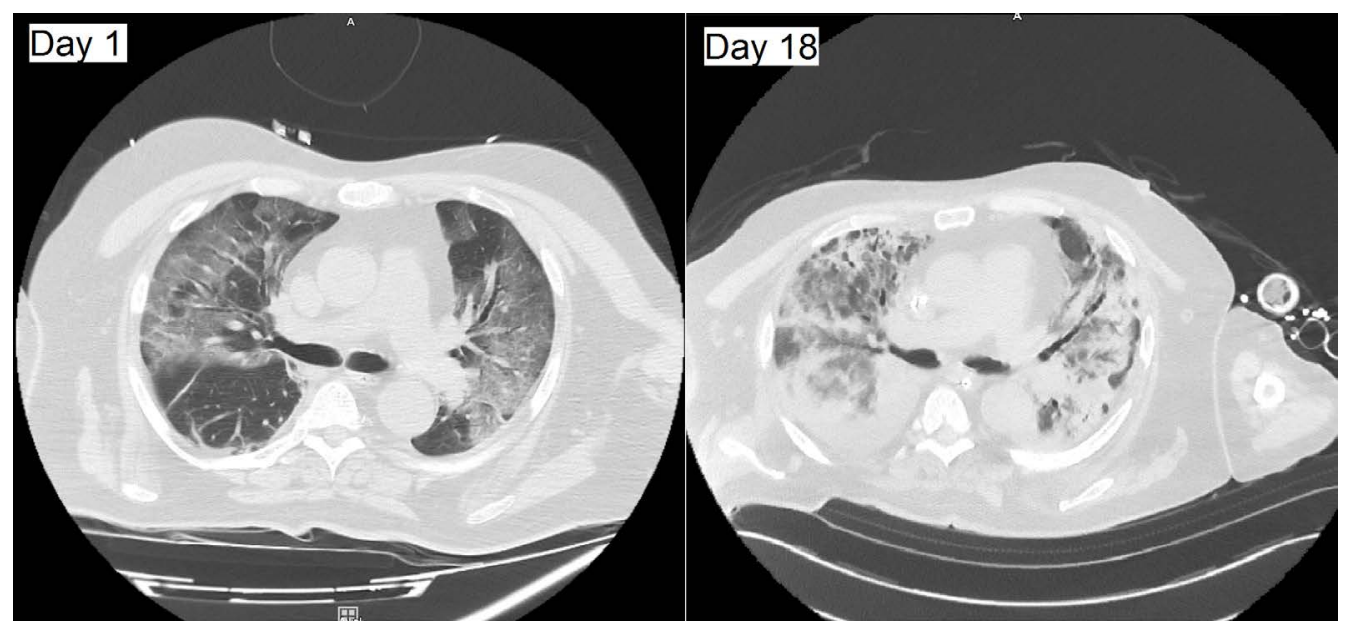

Figure 1: Comparison between Chest CT-scan at day 1 and day 18 in our first COVID-19 patient.

Table 3: Thrombotic antibodies.

\begin{tabular}{|l|l|}
\hline $\begin{array}{l}\text { Antiprothrombinase antibodies } \\
\text { No positive/Total No }\end{array}$ & $8 / 22$ \\
\hline $\begin{array}{l}\text { Antiß2GP1 antibodies } \\
\text { No positive/Total No }\end{array}$ & $3 / 22$ \\
\hline $\begin{array}{l}\text { Cardiolipin antibodies } \\
\text { No positive/Total No }\end{array}$ & $3 / 22$ \\
\hline
\end{tabular}

tients was $60 \pm 11$ years (range, 31 to 85 ); $74 \%$ were men. The mean duration of symptoms before ICU admission was $10 \pm$ 5 days. Forty-nine patients (50.5\%) came directly from home. Chronic medical conditions seen in this critically ill population were arterial hypertension in 49 patients (46.6\%), diabetes mellitus in 28 patients (28.9\%), dyslipidemia in 22 patients (22.7\%), obstructive sleep apnea in 18 patients (18.6\%), coronary artery disease 16 patients (16.5\%), ischemic stroke in 8 patients $(8.2 \%)$, chronic kidney disease in 8 patients $(8.2 \%)$, asthma in 8 patients $(8.2 \%)$, confirmed chronic obstructive pulmonary disease in 7 patients $(7.2 \%)$ and 3 patients $(3.1 \%)$ were current smokers.

\section{Laboratory data at hospital admission and imag- ing findings}

Table 2 shows the laboratory findings collected upon admission and during the first 72 hours. On admission, lympho- penia was common with a median lymphocyte count of 670 per cubic millimeter (interquartile range, 500 to 930). Arterial lactate was $1.3 \mathrm{mmol} / \mathrm{L}$ (interquartile range 1.09 to 1.77 ). C reactive protein was $155.5 \mathrm{mg} / \mathrm{L}$ (interquartile range, 103.5 to 210). Fibrinogen was $7 \mathrm{~g} / \mathrm{L}$ (interquartile range, 5.9-8.6) and D-Dimers were $1164 \mathrm{ng} / \mathrm{mL}$ (interquartile range 717 to 2663). Rhabdomyolysis was present in 40 patients (41\%).

During the course of the crisis, recurrent thrombotic events were observed. Thrombotic antibodies were tested at day 1 after ICU admission. Table 3 shows the findings for 22 patients.

Chest radiography obtained in all the patients on ICU admission showed bilateral pulmonary opacities. A chest computed tomographic (CT) scan was obtained in 10 patients; all the scans showed bilateral ground glass opacities. Pulmonary lesions were classified as moderate $(10-20 \%$ of the parenchyma) in 2 patients, extensive (25-50\% of the parenchyma) in 2 patients, severe (50-75\% of the parenchyma) in 3 patients and critical (> 75\% of the parenchyma) in 3 patients. No pulmonary embolism was observed. Figure 1 provides representative CT-scan images from a single patient, illustrating the rapid evolution of pulmonary opacities and the diffuse findings.

\section{Microbiologic findings}

Among the patients with laboratory-confirmed Covid-19, 76 patients also had nasopharyngeal swabs for influenza and 
Citation: Lakhanpaul M, Rosenthal DM, Lakhanpua M, et al. (2020) Reverse Innovation: Could Learning From LMIC Child Health Programmes Support HIC to Equitably and Efficiently Address Child Health Needs Post COVID-19?. Ann Public Health Reports 4(1):53-61

Table 4: Microbiologic findings.

\begin{tabular}{|c|c|c|}
\hline Infection analyses & No positive/Total No & \\
\hline Blood cultures & $0 / 90$ & \\
\hline Tracheal aspiration sputum culture & $5 / 41$ & $\begin{array}{l}\text { Klebsiella pneumoniae } \\
\text { Candida albicans } \\
\text { Methicillin sensitive Staphylococcus aureus } \\
\text { Aspergillus fumigatus } \\
\text { Candida glabrata }\end{array}$ \\
\hline Urine culture & $0 / 65$ & \\
\hline Urine antigen for Legionella pneumophilia & $0 / 83$ & \\
\hline Influenza PCR & $0 / 76$ & \\
\hline Respiratory Syncytial Virus PCR & $1 / 76$ & \\
\hline
\end{tabular}

PCR: Polymerase Chain Reaction.

Table 5: Characteristic of mechanical ventilation.

\begin{tabular}{|l|l|}
\hline \multicolumn{2}{|l|}{ Day 1 median values in supine position (IQR) } \\
\hline Plateau pressure $-\mathrm{cmH}_{2} \mathrm{O}$ & $25(22-27)$ \\
\hline Driving pressure $-\mathrm{cmH}_{2} \mathrm{O}$ & $11(10-13)$ \\
\hline $\mathrm{PaO}_{2}: \mathrm{FiO}_{2}-\mathrm{mmHg}$ & $143(114-208)$ \\
\hline Compliance $-\mathrm{mL} / \mathrm{cmH}_{2} \mathrm{O}$ & $38(32-43)$ \\
\hline Ve corrected $-\mathrm{L} / \mathrm{min}$ & $10.58(8.9-11.96)$ \\
\hline $\begin{array}{l}\text { Difference between administered } \mathrm{Vt} \text { vs. } \\
\text { targeted } \mathrm{Vt}-\mathrm{mL} / \mathrm{Kg}\end{array}$ & $16(1-31)$ \\
\hline
\end{tabular}

VeCorrected $=$ Ve $\times\left(\mathrm{pCO}_{2} / 40\right)$.

Table 6: Adjunctive therapies ( $\mathrm{No}=97$ ).

\begin{tabular}{|l|l|}
\hline Therapy - No (\%) & \multicolumn{2}{l|}{} \\
\hline Prone position (Day 1 to 3) & $29(29.9)$ \\
\hline Neuromuscular blockade & $89(91.7)$ \\
\hline Inhaled pulmonary vasodilators & $8(8.2)$ \\
\hline Extracorporeal Membrane Oxygenation & $4(4.1)$ \\
\hline Norepinephrine & $82(84.5)$ \\
\hline Dobutamine & $7(7.2)$ \\
\hline
\end{tabular}

respiratory syncytial virus (RSV) testing. Only one patient had a coinfection with RSV. Sputum samples from 41 patients were sent for bacterial culture. Only five were positive for bacterial growth; blood cultures of 90 patients were all negative (Table 4).

\section{Clinical course}

Patients were treated initially by antibiotics (Cefotaxime and Spiramycine) and Oseltamivir. They were deeply sedated and neuromuscular blockade was unusually necessary for up to 7 days. Depth of sedation was monitored by Bispectral Index Score (BIS), and neuromuscular blockade by train-of-four (TOF). Prophylactic anticoagulation was also administered.

Four patients were treated by High-flow oxygen by nasal cannula, and no patient was treated by noninvasive ventilation, due to the risk of viral aerosolisation.
Ninety-three patients (95.8\%) were intubated and mechanically ventilated. $\mathrm{PaO}_{2}: \mathrm{FiO}_{2}$ ratios were consistent with moderate-to-severe ARDS (median 143, interquartile rang 114 to 208). The median driving pressure (the difference between plateau pressure and positive end expiratory pressure [PEEP]) on Day 1 of mechanical ventilation was $11 \mathrm{cmH}_{2} \mathrm{O}$ (interquartile range, 10 to 13 ).

The median pulmonary compliance on Day 1 was $38 \mathrm{~mL} /$ $\mathrm{cmH}_{2} \mathrm{O}$ (interquartile range 32 to 43) (Table 5).

Twenty-nine patients (29.9\%) were placed in a prone position, $89(91.7 \%)$ received neuromuscular blockade, and 8 $(8.2 \%)$ received inhaled pulmonary vasodilators. Eighty-two patients $(84.5 \%)$ presented with hypotension requiring low doses of vasopressors, without clear evidence of concurrent infection (Table 6).

Thirty-two patients had completed echocardiograms (32.9\%). Three of them showed previously unknown left ventricular dysfunction and only one had high left ventricular filling pressure assessed by $\mathrm{E} / \mathrm{e}^{\prime}$ criteria.

\section{Outcomes}

The follow-up of our patients was relatively complex to set up since 60 (61.9\%) medically stabilized patients had to be transferred to other ICU. As of April $2^{\text {nd }}, 60$ (61.8\%) medically stabilized patients had to be transferred to other ICU, 18 (18.5\%) died, 8 (8.2\%) had been discharged but remained in the hospital and 15 (15.5\%) were still ventilated in our unit.

\section{Discussion}

In this cohort study, we report the clinical characteristics of patients with COVID-19 hospitalized in ICU in the early stage of the disease. Due to our hospital reorganization many patients had to be transferred to other ICU either in the Alsace area or further in the country as well as in cross-border.

Age of patients (mean 60 years) and sex ratio (74\% males) were similar to Chinese, Italian and American cohorts [6-8]. Other risk factors were similar in our patients: elevated BMI $\left(31.4 \mathrm{~kg} / \mathrm{m}^{2}\right)$, hypertension, diabetes mellitus, and dyslipidemia. Obstructive sleep apnea prevalence (18\%) is related to obesity. 


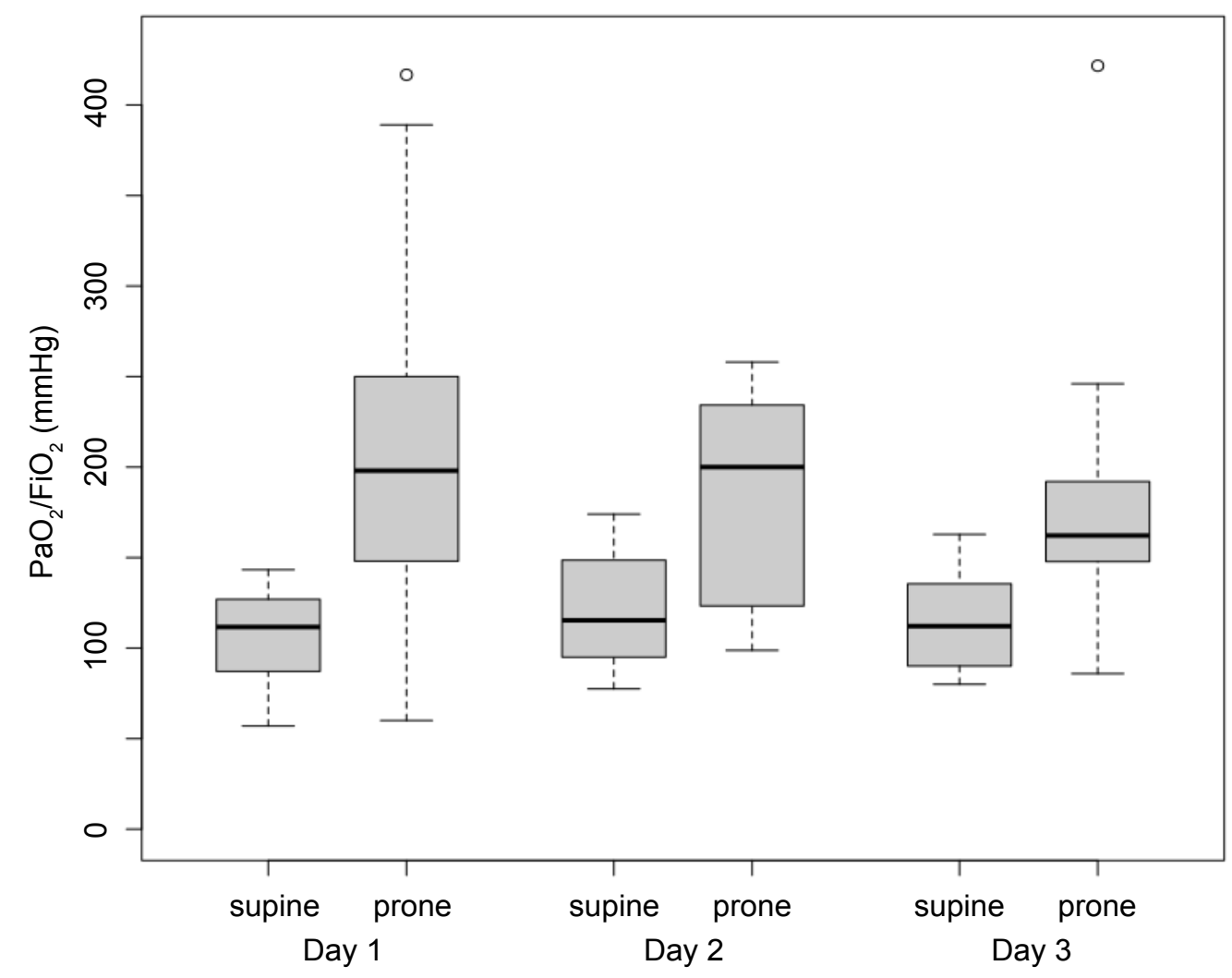

Figure 2: $\mathrm{PaO}_{2}: \mathrm{FiO}_{2}$ ratios evolution in supine and prone position.

Due to the massive flood of patients affected by this emergent disease admitted to Emergency Department and ICU, we rapidly set up a protocol for their management.

Respiratory distress stood as the first critical symptom of the disease. Almost all the patients (96\%) required intubation and mechanical ventilation with high $\mathrm{FiO}_{2}$ and high PEEP to ensure proper oxygenation. Tidal volume was targeted at 6 $\mathrm{mL}$ per kilogram of predicted body weight [9] and PEEP was titrated according to the best respiratory-system static compliance.

In patients with a $\mathrm{PaO}_{2}: \mathrm{FiO}_{2}$ ratio less than $150 \mathrm{mmHg}$ during the first three days ( $30 \%$ of total), prone positioning [10] was performed with a sustainable benefit (Figure 2).

Many arguments are in favor of inflammatory pulmonary edema and ARDS: Low pulmonary compliance, increased dead space reflected by corrected minute ventilation $>10 \mathrm{~L} /$ min [11] and absence of cardiac failure or fluid overload by echocardiogram assessment. COVID-19 histological findings show that thrombosis is commonly observed in small vessels and micro vascular in lungs accompanying diffuse alveolar damage [12].

Post-mortem data showed prominent alveolar edema, hyalinosis (intra-alveolar proteinosis) and fibrin deposition with pneumocytes viral cytopathic change and immune cell infiltration including lymphocytes is typical of ARDS [13]. Our patients' exhibit features of systemic hyper-inflammation and coagulation disturbances consistent with the description of Yao, et al. [13].
In a large prospective cohort study conducted in a tertiary teaching hospital in Wuhan, China, a high prevalence of kidney disease was observed in hospitalized patients with COVID-19. More than $40 \%$ of them had evidence of kidney disease, with elevated serum creatinine and blood urea nitrogen values in over $13 \%$ of them [14]. Renal function of our patients was initially normal. Forty patients $(41 \%)$ had mild to severe rhabdomyolysis. Proteinuria as well as hypoalbuminemia was observed in almost all of them. Further investigations have to be done to explore renal lesions.

Hemodynamic patterns were mostly in favor of hypovolemia probably due to dehydration consecutive to hyperthermia, anorexia, diarrhea, and polypnea which are early manifestations of COVID-19. Vasopressors had to be administered at low doses particularly after deep sedation and mechanical ventilation.

Co-infection was scarcely present in our patients. Only five tracheal aspirates were positive and one RSV PCR was obtained by nasopharyngeal swab. Acquired infections could not be assessed in the large majority of our cohort because of the high rate of secondary transfer.

\section{Conclusion}

Severe form of Covid-19 is marked by systemic hyper-inflammation and coagulation disturbances associated with a new pattern of ARDS. Almost all the patients required intubation and mechanical ventilation with high $\mathrm{FiO}_{2}$ and high PEEP to ensure proper oxygenation. In patients with a $\mathrm{PaO}_{2}: \mathrm{FiO}_{2}$ ratio less than $150 \mathrm{mmHg}$ (30\% of total), prone positioning was performed with a sustainable benefit. 
Citation: Lakhanpaul M, Rosenthal DM, Lakhanpua M, et al. (2020) Reverse Innovation: Could Learning From LMIC Child Health Programmes Support HIC to Equitably and Efficiently Address Child Health Needs Post COVID-19?. Ann Public Health Reports 4(1):53-61

\section{Ethics Approval}

The study was approved by the local ethics committee.

\section{Consent for Publication}

All authors have confirmed the manuscript and approved the publication of the manuscript. The corresponding author has completed the "Consent for publication".

\section{Availability of Data and Material}

The datasets used and/or analyzed during the current study are available from the corresponding author on reasonable request.

\section{Competing Interests}

The authors have no competing of interest nor any financial interest in any product mentioned in this paper.

\section{Funding}

Not applied.

\section{Authors' Contributions}

All authors were responsible for the concept, revision and approval of this manuscript. SD performed statistical analysis. All authors read and approved the final manuscript.

\section{Acknowledgements}

In the context of COVID-19 crisis, authors would like to greatly acknowledge all the medical and non-medical teams of the Mulhouse Medical ICU working in constrained environment.

\section{References}

1. Zhu N, Zhang D, Wang W, et al. (2020) A novel Coronavirus from patients with Pneumonia in China, 2019. N Engl J Med 382: 727-733.

2. Li Q, Guan X, Wu P, et al. (2020) Early transmission dynamics in Wuhan, China, of novel coronavirus-infected Pneumonia. N Engl J Med 382: 1199-1207.

3. Wu JT, Leung K, Leung GM (2020) Now casting and forecasting the potential domestic and international spread of the 2019nCoV outbreak originating in Wuhan, China: A modelling study. The Lancet 395: 689-697.

4. Rothan HA, Byrareddy SN (2020) The epidemiology and pathogenesis of coronavirus disease (COVID-19) outbreak. J Autoimmun 109: 102-433.

5. (2020) Communique Coronavirus Covid 19 Grand Est - Nouveau point de situation.

6. Yang X, Yu Y, Xu J, et al. (2020) Clinical course and outcomes of critically ill patients with SARS-CoV-2 pneumonia in Wuhan, China: A single-centered, retrospective, observational study. Lancet Respir Med 8: 475-481.

7. Grasselli G, Zangrillo A, Zanella A, et al. (2020) Baseline characteristics and outcomes of 1591 patients infected with SARSCoV-2 admitted to ICUs of the lombardy region, Italy. JAMA 323: 1574-1581.

8. Bhatraju PK, Ghassemieh BJ, Nichols M, et al. (2020) Covid-19 in critically ill patients in the seattle region - case series. $\mathrm{N}$ Engl J Med 382: 2012-2022.

9. ARDS Definition Task Force, Ranieri VM, Rubenfeld GD, et al. (2012) Acute respiratory distress syndrome: The berlin definition. JAMA 307: 2526-2533.

10. Guérin C, Reignier J, Richard JC (2013) Prone positioning in the acute respiratory distress syndrome. N Engl J Med 369: 980-981.

11. Acute Respiratory Distress Syndrome Network, Brower RG, Matthay MA, et al. (200) Ventilation with lower tidal volumes as compared with traditional tidal volumes for acute lung injury and the acute respiratory distress syndrome. N Engl J Med 342: 1301-1308.

12. Zhang T, Sun LX, Feng RE (2020) Comparison of clinical and pathological features between severe acute respiratory syndrome and coronavirus disease 2019. Zhonghua Jie He He Hu Xi Za Zhi 43: 496-502.

13. Yao XH, Li TY, He ZC, et al. (2020) A pathological report of three COVID-19 cases by minimally invasive autopsies. Zhonghua Bing Li Xue Za Zhi 49: 411-417.

14. Cheng Y, Luo R, Wang K, et al. (2020) Kidney disease is associated with in-hospital death of patients with COVID-19. Kidney Int 97: 829-838.

DOI: $10.36959 / 856 / 493$ 